\title{
Tomasz Lechowicz*
}

\section{GOSPODARSTWA DOMOWE JAKO ŹRÓDLO FINANSOWANIA NIERUCHOMOŚCI W POLSCE I W WIELKIEJ BRYTANII W LATACH 2001-2013}

\author{
HOUSEHOLDS AS A SOURCE OF REAL ESTATE FINANCING \\ IN GREAT BRITAIN IN 2001-2013 YEARS
}

\begin{abstract}
Households had to deal with problems that arise from the financial institutions and stock markets problems. A consequence of financial crisis on households was restriction in granting credits by the banks as well as sudden rise in prices of new credits. Another visible by households a consequence of recession was the collapse of stock market and institutions operating on this market. Recession destabilized the stock markets, thus reduced possibilities to achieve investment incomes. Quick collapse of the bond and shares market resulted in a huge losses to investors. Households form one of active groups of individual investors, however from the other side they are participants in investment funds. Household savings were deposited on the stock market, and at the time of stock market collapse the households lost money which were directed to stock market directly or through investment funds.
\end{abstract}

Key words: bank, England, households, financial,

JEL Classification: L26, L53

\section{Wstęp}

Sektor finansów w 2007 roku uległ jednemu z największych kryzysów od lat 30. minionego wieku. Na tak złe funkcjonowanie systemu finansowego złożyło się wiele przyczyn, takich jak udzielanie złych kredytów, hazard w postaci derywatów, które w ostateczności doprowadziły do bankructwa wiele banków. Również lata nieprzejrzystego księgowania i złożonych produktów opracowanych tak,

\footnotetext{
* Mgr, Uniwersytet Ekonomiczny w Krakowie.
} 
aby wprowadzić w błąd regulatorów i inwestorów, negatywnie wpłynęły na system finansowy.

Próbując zaprezentować powyższe zagadnienie, wykorzystano dostępne dane empiryczne dotyczące gospodarstw domowych w Polsce i w Wielkiej Brytanii. Przedmiotem analizy są przede wszystkim dane makroekonomiczne, takie jak: PKB, inflacja, bezrobocie, popyt na kredyt itp. Nie wyczerpują one czynników makroekonomicznych determinujących sytuację gospodarczą gospodarstw domowych w Wielkiej Brytanii i w Polsce, jednak niewątpliwie należą do najważniejszych. W artykule zostanie również przedstawiony model Minsky'ego, który przewidział powstanie kryzysu finansowego na długo przed jego wybuchem.

\section{Istota bańki spekulacyjnej - model kryzysu finansowego Minsky'ego}

W literaturze przedmiotu można spotkać się z tradycyjnym modelem kryzysów finansowych, który obejmuje wzrost cen określonych aktywów (akcje, nieruchomości, waluty itp.) i następującą po tym znaczną korektę ich wyceny. Jednym z nich jest model Hymana P. Minsky'ego. Dotyczy on warunków rynkowych panujących m.in. w Wielkiej Brytanii. Minsky, podobnie jak I. Fischer, dużą wagę przywiązywał do zachowania wysoko zadłużonych kredytobiorców, szczególnie tych, którzy inwestowali w nieruchomości, licząc, że w krótkim czasie uzyskają zwrot z inwestycji i odniosą korzyść w postaci zysku ${ }^{1}$.

Minsky wykazał, w jaki sposób stabilność ekonomiczna sprzyja rosnącej, czasem nadmiernej kreacji kredytu, prowadząc do niestabilności systemu finansowego oraz „bańki” spekulacyjnej, a w konsekwencji - do zahamowania wzrostu gospodarczego, kryzysu finansowego. Równocześnie uważał, iż takie kryzysy nie zdarzają się często.

$\mathrm{W}$ początkowej fazie boomu na giełdzie inwestorzy podejmują decyzję na podstawie analizy czynników fundamentalnych. Czekają na zwiększenie się własnych inwestycji oraz zysk. Racjonalną przesłanką takich oczekiwań jest sytuacja, w której szybkiemu wzrostowi gospodarczemu towarzyszy niska inflacja. Po pewnym czasie boom może przekształcić się w stan określony jako bąbel spekulacyjny². Dzieje się to wtedy, gdy celem zakupu akcji jest tylko wzrost ich cen. Oczekiwania inwestorów stają się nieracjonalne, akcje nabywa się tylko dlatego, że ich indeks rośnie. Przyspieszenie bąbla spekulacyjnego następuje w sytuacji, gdy spekulacja, jak pisze Charles Kindleberger, „wciąga także tych, którzy zazwyczaj trzymają się od niej z daleka"’3. Nigdy nie wiadomo, czy i kiedy indeks się załamie ${ }^{4}$.

${ }^{1}$ W. Nawrot, Globalny kryzys finansowy XXI wieku. Przyczyny, przebieg, skutki, prognozy, CeDeWu, Warszawa 2009, s. 15.

${ }^{2}$ A. Sławiński, Rynki finansowe, PWE, Warszawa 2006, s. 160-162.

${ }^{3}$ Ch. Kindleberger, Szaleństwo, panika, krach, WIG Press, Warszawa 1999, s. 25.

${ }^{4}$ R.J. Shiller, Irrational Exuberance, Princeton University Press, New Jersey 2001, s. 78-95. 
Minsky udowodnił, że podaż kredytu rośnie w okresie dynamicznego wzrostu gospodarczego, a spada, kiedy gospodarka zwalnia. Wskazał na pojawienie się w systemie ekonomicznym pewnego rodzaju szoku, który mając odpowiednią siłę, może generować duże zyski dla przynajmniej jednego ważnego sektora gospodarczego. Polega to na tym, że wskutek pewnego szoku rośnie popyt na określone dobra i usługi. To z kolei po pewnym czasie napotyka na ograniczenie ze strony podaży, co w konsekwencji powoduje wzrost cen. Rosnąca wartość automatycznie przekłada się na zyski firm, które zwiększają moce produkcyjne, a także zachęcają nowe przedsiębiorstwa do angażowania się w ten rynek.

$\mathrm{W}$ trakcie wzrostu gospodarczego pojawia się euforia, która polega na kupowaniu dóbr oraz papierów wartościowych najszybciej rozwijającej się branży. Z upływem czasu coraz więcej firm włącza się w spekulacyjny wyścig, chcąc skorzystać z nadarzającej się okazji do zarobienia łatwych pieniędzy. W tym samym czasie banki zaczynają zwiększać własną ofertę kredytową, udzielając nowych kredytów z przeznaczeniem na zakup nieruchomości lub papierów wartościowych.

Euforia prowadzi do nadmiernego optymizmu. Następuje przeszacowanie stopy zwrotu z inwestycji, następnie, w fazie ekspansji, pojawia się zmniejszenie liczby kredytów zagrożonych. Banki chcą więcej pożyczać pieniędzy, zaniżając standardy kredytowe, co powoduje wzrost zadłużenia. Przyszłe zyski skłaniają firmy oraz gospodarstwa domowe do zaciągania następnych kredytów mających na celu zakup kolejnych aktywów. Jest to możliwe dzięki niskiemu poziomowi wskaźnika długu do kapitału własnego.

Model Minsky'ego dotyczy zachowania kredytobiorców, jak i banków. W pierwszej fazie kryzysu finansowego zarówno w bankach, jak i u tych, którzy korzystają z kredytów, wzrasta optymizm. Prowadzi to do niedoszacowania ryzyka kredytowego wśród banków oraz podwyższania prognoz rentowności inwestycji wśród kredytobiorców. Następnie:

- banki zwiększają limity kredytów dla firm oraz gospodarstw domowych, walczą na rynku kredytowym o klientów oraz zmniejsza się awersja do ryzyka;

- gospodarstwa domowe zaciągają kredyty na zakup nieruchomości (pierwszy zakup lub kolejny zakup nieruchomości w celach inwestycyjnych) bądź kredyty konsumpcyjne, przedsiębiorstwa zaciągają kredyty inwestycyjne, na zakup aktywów w celu osiągnięcia zysków - na tym etapie powstaje spekulacja.

Według Minsky'ego następuje teraz proces zwany follow the leader. Polega on na włączaniu w spekulacyjny wyścig nowych podmiotów, które widząc zachowania innych uczestników, również chcą skorzystać z nadarzającej się okazji. W ten sposób tworzy się bańka spekulacyjna.

Boom na podstawie teorii Minsky’ego jest napędzane przez podaż kredytów. Warunkiem jego zaistnienia jest niestabilna działalność kredytowa banków. Polega ona na tym, że w niektórych okresach zachowanie banków jest pełne optymizmu, natomiast $\mathrm{w}$ innym czasie przejawia się nadmiernym wstrzymaniem akcji kredytowej, co prowadzi do zacieśnienia podaży kredytu. 
Hyman Minsky, profesor ekonomii na Uniwersytecie Waszyngtona w St. Louis, ostrzegał, że normalne funkcjonowanie gospodarki dąży do finansowych kryzysów, inflacji, deprecjacji walut, bezrobocia i biedy w warunkach, w których można by zagwarantować powszechny dobrobyt. Krótko mówiąc, złożony, finansowy kapitalizm jest immanentnie wadliwy ${ }^{5}$.

Uważał on, że bańki spekulacyjne i pojawiające się po nich załamania finansowe stanowią wspólną część nowoczesnego kapitalizmu. Nie są one wynikiem błędnych decyzji jednostek, ale stałym elementem życia gospodarczego w systemie kapitalistycznym, gdzie układ finansowy nie podlega regulacji.

Minsky wyodrębnił trzy rodzaje inwestycji. Pierwsze stanowi inwestowanie spekulacyjne, gdzie pożyczkobiorca jest w stanie płacić za odsetki od kredytów, ale nie może spłacić całego długu. Drugie inwestowanie hedgingowe - pożyczkobiorca jest w stanie pokryć cały kredyt z osiąganych dochodów. Ostatnim rodzajem inwestycji, według Minsky’ego, jest inwestycja w systemie Ponziego. Cechuje się tym, że na początku pożyczkobiorcy nie stać na spłatę całego kredytu z własnych dochodów. Bank funkcjonujący w systemie Ponziego stale szuka nowych osób chcących zainwestować. Pieniądze wpłacane przez owych inwestorów są przeznaczane na pokrycie zobowiązania wobec jego wcześniejszych kredytodawców. Według Minsky'ego, działanie instytucji finansowych na podstawie systemu Ponziego, choć z punktu widzenia prawa stanowi nielegalne przedsięwzięcie, jest wynikiem przerostu bańki kredytowej.

W okresie równomiernego wzrostu gospodarczego banki wykazują tendencję do zmiany profilu funkcjonowania $\mathrm{z}$ jednostek stabilnych $\mathrm{w}$ jednostki spekulacyjne. Wówczas działają według systemu Ponziego. Jak mówił Minsky, jeśli gospodarka, w ramach której działa znacząca liczba instytucji spekulacyjnych, odnotowuje wysoką inflację, a rząd próbuje ją powstrzymać za pomocą restrykcyjnej polityki monetarnej, to instytucje spekulacyjne zaczynają działać według systemu Ponziego. Oznacza to, że aktywa netto instytucji działających, zgodnie z tym układem, „rozpływają się w powietrzu”. W rezultacie instytucje cierpiące na niedobory płynnej gotówki będą próbowały wzmocnić swoją pozycję, wyprzedając się, co może z dużą dozą prawdopodobieństwa skutkować załamaniem wartości wszystkich aktywów ${ }^{6}$.

Zasadę tę potwierdziły wydarzenia $\mathrm{z}$ lat 2005-2007. Jednostki finansowe, które udzielały kredyty subprime zaczęły funkcjonować według systemu Ponziego. Straty, które były generowane przez te jednostki, pokrywali nowi inwestorzy. Zdecydowana większość banków to spekulanci. Pod wpływem wzrostu cen ropy naftowej oraz wzrastających stóp procentowych zaczęły upadać jednostki finansowe, które sprzedawały kredyty hipoteczne. Następne były fundusze hedgingowe, a na końcu same placówki bankowe.

\footnotetext{
${ }^{5}$ H. M. Minsky, Stabilising an Unstable Economy, New York 2008, s. 320.

${ }^{6}$ Ibidem.
} 
Minsky uważał, że najlepszą odpowiedzią na kryzys gospodarczy jest pomoc państwa polegająca na tym, że rząd powinien zwiększyć deficyt budżetowy. Wówczas bank centralny staje się odpowiedzialny za zwiększenie podaży pieniądza w gospodarce. Te właśnie działania zastały wykorzystane m.in. przez Wielką Brytanię, jednak nie były zbyt skuteczne. Miliardy funtów, które wpompowano w gospodarkę w postaci gotówki, kredytu oraz wydatków publicznych w niewielkim stopniu przyczyniły się do wzrostu gospodarczego. Spowodowały natomiast inflację, pod wpływem której ceny poszybowały w górę.

Zdaniem Minsky'ego, dobrym rozwiązaniem mającym na celu stabilizację gospodarki jest uspołecznienie systemu bankowego. Ma ona przynieść wysoki poziom konsumpcji oraz stabilny kapitalizm. „Uspołecznienie finansowych gigantów jak najbardziej sprzyja istnieniu dużego, rozwijającego się, prosperującego sektora prywatnego. Ta synteza pozwoliłaby utrzymać wysoki poziom konsumpcji i mogłaby dla wolnej przedsiębiorczości i odważnych przedsięwzięć gospodarczych stworzyć lepsze warunki niż te, które zapewniają obecny system" - pisał Minsky ${ }^{7}$. To właśnie on przewidział w swojej teorii przyszły potężny zastrzyk państwowej gotówki i gwarantowanego kredytu, który uratuje system bankowy. Przejęcie kontroli nad dużą częścią sektora bankowego przez państwo, pomoc kredytowa dla placówek bankowych oraz cięcia podatkowe mają zagwarantować wyjście z kryzysu.

\section{Rynek nieruchomości oraz gospodarstwa domowe w czasie kryzysu}

Kryzysy ekonomiczne towarzyszą ludziom od setek lat. Ekonomiści zauważyli, że począwszy od XIX gospodarka rynkowa przeżywa je dość regularnie, co 10, 12, 25 lat. Mimo tego każdy kryzys nadchodzi niespodziewanie i trudno jednoznacznie odczytać przesłanki o nadchodzącej dekoniunkturze. Podobna sytuacja nastąpiła w 2007 roku w Stanach Zjednoczonych, kiedy pękła bańka spekulacyjna na rynku nieruchomości (housing bubble), co spowodowało gigantyczne zachwianie sektora bankowego. Podniesienie stóp procentowych przez Federal Reserve Bank zwiększyło raty kredytów hipotecznych, doprowadzając do niewypłacalności milionów Amerykanów. Inwestycje w nieruchomości zaczęły generować straty, dlatego liczba mieszkań zaczęla gwałtownie rosnąć, pogłębiając spadek cen. W okresie od lipca do grudnia 2007 roku zajęto ok. 1,3 mln mieszkań, a ich wartość zmniejszyła się średnio o $20 \%$.

Kłopoty sektora nieruchomości i banków wywołały panikę na giełdzie. W tym czasie zbankrutowało wiele instytucji finansowych oferujących łatwe kredyty

${ }^{7}$ H.P. Mynsky, John Maynard Keynes, New York 2008, s. 164. 
osobom nieposiadającym wypłacalności. Największy krach nastąpił po upadku jednego z czołowych amerykańskich banków - Lehman Brothers. Od tego momentu kryzys zaczął się szybko rozprzestrzeniać, zarówno na inne sektory gospodarki amerykańskiej, jak i inne państwa ${ }^{8}$.

Pierwszym krajem, który odczuł skutki kryzysu w USA była Wielka Brytania. We wrześniu 2008 roku na skraju bankructwa znalazł się Halifax Bank of Scotland - HBOS. Później został wykupiony przez Lloyds TSB. Z kolei Bradford \&Bingley, bank specjalizujący się w udzielaniu kredytów z przeznaczeniem na nieruchomości, został znacjonalizowany. Do końca marca 2009 roku Wielka Brytania dokapitalizowała sektor bankowy kwotą 63 mld euro i udzieliła gwarancji bankowych na kwotę 294,26 mld euro9.

W Polsce spowolnienie na rynku nieruchomości pojawiło się później niż w innych krajach Europy. Ze względu na brak instytucji udzielających ryzykowne kredyty hipoteczne nie powtórzyła się sytuacja upadłości znaczących instytucji finansowych. Ponadto nie wystąpiły również duże problemy z wypłacalnością kredytobiorców. Niemniej jednak znacznie zaostrzono warunki udzielania kredytów. To doprowadziło do spadku zakupu nieruchomości. Faktem było również odczuwalne spowolnienie gospodarcze, które spowodował odpływ zagranicznych inwestorów i mniejszy popyt na polskie towary eksportowe ${ }^{10}$.

Gospodarstwa domowe musiały się zmierzyć z trudnościami, które wynikały z problemów instytucji finansowych oraz rynków papierów wartościowych. Konsekwencją kryzysu finansowego dla nich było ograniczenie kredytów przez placówki bankowe, a także gwałtowny wzrost cen nowych kredytów. Na podstawie wcześniej przedstawionej teorii Minsky’ego można stwierdzić, że instytucje finansowe w momencie recesji zmieniły model działania, przechodząc ze skrajnie nieostrożnej w okresie boomu do ograniczenia akcji kredytowej na skutek zwiększającego się ryzyka. Banki w obawie przed wzrostem ryzyka kredytowego nie tylko na rynku międzybankowym, ale również w gospodarce, ograniczały podaż kredytu. Co więcej, zaostrzały warunki udzielania kredytów, gdzie przy rosnących cenach finansowania na systemie międzybankowym przekładały się na wyższe wartości kredytów dla gospodarstw domowych. Owa sytuacja miała miejsce w czasie upadku Lehman Brothers, gdzie instytucje bankowe z dnia na dzień radykalnie ograniczyły akcję kredytową. Wiele banków w tym czasie musiało wstrzymać udzielanie kredytów, ponieważ były uzależnione od finansowania na rynku międzybankowym, który na skutek ryzyka zamarł. Zatem wybuch global-

${ }^{8}$ F. Kusiak, Kryzys na rynku nieruchomości ze szczególnym uwzględnieniem sprzedaży niezabudowanych dziatek gruntu we Wrocławiu w latach 2008-2009, „Kultura - Historia - Globalizacja” 2011, nr 9, s. 47-49.

9 J. Adamiec, P. Russel, Kryzys finansowy. Wybrane zagadnienia, Wydawnictwo Sejmowe, Warszawa 2009, s. 8-9.

${ }^{10}$ F. Kusiak, Kryzys finansowy..., s. 47-49. 
nego kryzysu finansowego odciął gospodarstwa domowe od pobierania zobowiązania finansowego, które było przeznaczane na cele mieszkaniowe, jak również konsumpcyjne.

Kolejna odczuwalną przez gospodarstwa domowe konsekwencją recesji okazało się załamanie się rynku papierów wartościowych oraz instytucji działających na tym rynku. Recesja zdestabilizowała tę część gospodarki, zmniejszając możliwości osiągania dochodów z inwestycji kapitałowych. Szybkie załamanie się rynku obligacji oraz akcji przyniosło inwestorom ogromne straty. Gospodarstwa domowe tworzą jedną z aktywnych grup inwestorów indywidualnych. Natomiast z drugiej strony są uczestnikami funduszy inwestycyjnych. Oszczędności gospodarstw domowych lokowano na rynku papierów wartościowych. W momencie załamania się rynku papierów wartościowych gospodarstwa straciły pieniądze, które miały być skierowane na rynek papierów wartościowych bezpośrednio lub za pośrednictwem funduszy inwestycyjnych.

Uczestnikami funduszy emerytalnych są również gospodarstwa domowe. Kryzys finansowy negatywnie wpłynął na ludzi, którzy w tym okresie przechodzili na emerytury. Obok funduszy inwestycyjnych, fundusze emerytalne były znaczącą grupą poszkodowanych instytucji. W tym czasie to one dokonały dużych inwestycji nie tylko w akcje i obligacje, ale również inwestowały w segment ryzykownych papierów wartościowych. Instrumenty te były zbudowane z ryzykownych kredytów udzielonych z segmencie subprime, ale miały w nazwie termin obligacji, a także posiadały wysoki rating i dlatego mieściły się w obszarze dopuszczalnych przez fundusze emerytalne lokat. Gwałtowny spadek wartości portfeli funduszy emerytalnych pod wpływem kryzysu finansowego spowodował zmniejszenie wartości emerytur. Przede wszystkim dotyczyło to tych osób, które właśnie przechodziły na emerytury. Wiele osób wstrzymywało się z przejściem na emerytury, licząc, że w niedalekiej przyszłości nastąpi wzrost wartości aktywów inwestycyjnych.

\section{Najważniejsze wydarzenia przedstawiające powstanie kryzysu finansowego w Wielkiej Brytanii}

Za istotne zdarzenia, które obrazują proces powstawania kryzysu finansowego na terenie państwa brytyjskiego, uznaje się daty:

- 14 września 2007 roku bank Northern Rock traci płynność finansową i jest zmuszony szukać pomocy w Banku Centralnym Anglii, który w ostateczności przejmuje bank;

- 26 listopad 2007 roku bank HSBC ogłasza 45 mld USD bail-out dla własnych niebankowych instytucji finansowych;

- 21 kwiecień 2008 roku Royal Bank of Scotland, w celu poprawienia sytuacji kapitałowej po zakupie ABN Amro, podwyższa kapitał o 12 mld funtów; 
- 16 września 2008 roku następuje spadek wartości akcji spowodowany brakiem dostępu banku do finansowania. Następnego dnia zostaje przejęty przez Lloyds TSB.

System finansowy w Wielkiej Brytanii kierował się ku recesji i miał przynieść upadek źle zarządzanych instytucji finansowych. Ceny udziałów brytyjskiego banku Bradford\&Bingley, którego działalność oparta była na kredytach typu subprime, spadła w wrześniu 2008 roku do 20 pensów, mimo że w 2006 roku wynosiła 536 pensów. Obawy klientów związane z możliwością upadku placówki bankowej powodują wycofanie depozytów banków wartych dziesiątek milionów funtów. Pod wpływem tych wydarzeń rząd brytyjski nacjonalizuje tę instytucję. Następnie sprzedaje część depozytową tego banku bankowi Santander, natomiast jego długi przejął brytyjski skarb państwa.

Kolejne trzy potężne placówki bankowe uzależnione od zamrożonego rynku kredytów, czyli HBOS, Loyds TSB i Royal of Scotland, także zanotowały spadek notowań swoich akcji we wrześniu 2008 roku.

6 października 2008 roku rząd Wielkiej Brytanii uruchomił system gwarancji depozytów. Akcje brytyjskich banków gwałtownie spadły, najbardziej straciły HBOS oraz RBS - około 20\% swojej wartości.

Kryzys finansowy uwidocznił problemy brytyjskich instytucji bankowych. W odróżnieniu od banków amerykańskich problemem banków w Wielkiej Brytanii nie było silne zaangażowanie w kredyty typu subprime. Ich trudności związane były z silnym uzależnieniem od krótkoterminowych kredytów na światowym rynku pieniężnym, które nie tylko zostało ograniczone do minimum, ale, jeśli jakiś bank mógł pożyczać, to cena za pożyczone pieniądze urosła kilkakrotnie w krótkim czasie.

7 października 2008 roku nastąpił kolejny gwałtowny spadek akcji banków Wielkiej Brytanii. Podano informację, że prezesi placówek będą prosić o pomoc na Downing Street, spowodowała, że RBS stracił $40 \%$ swojej wartości, a HBOS około $35 \%$. Tego samego dnia rząd ogłosił, że 25 mld funtów przeznaczy na zakup akcji upadających banków. Co więcej, z kolejnych 25 mld funtów utworzy rezerwy. Udzielił również gwarancji na 400 mld funtów, by odciążyć banki z zaciągniętych przez nie krótko- i średnioterminowych pożyczek. Te działania spowodowały, że brytyjska giełda zaczęła odrabiać straty. Jednak tydzień później rząd brytyjski musiał wyłożyć kwotę 37 mld funtów, by wykupić $60 \%$ udziałów RBS oraz $40 \%$ konsorcjum Lloyds-HBOS.

8 października 2008 roku nastąpiła pierwsza w historii akcja wspólnego obniżania stóp procentowych przez banki centralne. Te działania miały zapewnić instytucjom bankowym stały dopływ do kredytu.

9 października 2008 roku rząd Islandii znacjonalizował jeden z największych banków w kraju. System finansowy tego kraju był winien 300 tysiącom Brytyjczyków pieniądze, których nie był w stanie oddać. Rząd Wielkiej Brytanii wszedł na drogę prawną, by odzyskać środki finansowe. Powołał się na zapisy ustawy o zwalczaniu terroryzmu, aby móc przejąć aktywa banku. 
W porównaniu do USA działania rządu brytyjskiego były dość skromne. W tym czasie zapowiedziano obniżkę podatku VAT, która miała pomóc wrócić gospodarce Wielkiej Brytanii na ścieżkę wzrostu gospodarczego. Ustanowiono krótkoterminowe obniżki podatków dla najuboższych oraz większe podatki dla klasy średniej.

Powodem takich przedsięwzięć była dziura budżetowa, ponieważ finanse okazały się uzależnione od podatków odprowadzanych przez sektor finansowy, a przychody z podatków w ostatnich miesiącach zaczęły spadać. Rząd Gordona Browna został zmuszony do zwiększenia długu publicznego, który był utrzymywany przez ostatnie 10 lat na poziomie 40 do co najmniej $60 \%$.

19 października 2008 roku banki podpisały umowę z władzami kraju dotyczącą zwiększenia ilości kredytu dla gospodarstw domowych oraz przedsiębiorstw. Dzięki temu ich straty, powstałe na skutek złych inwestycji, zostały zamortyzowane przez rządowy plan ubezpieczeniowy. Northern Rock został znacjonalizowany, RBS przekazał kolejne $10 \%$ swoich udziałów rządowi, natomiast 50 mld funtów przekazano przez Bank Anglii najważniejszym firmom z wyjątkiem banków komercyjnych. Ważne były też następne wydarzenia:

- 7 listopad 2008 roku - nadzwyczajny szczyt Unii Europejskiej dotyczący kryzysu finansowego;

- 15 listopad - szczyt grupy G20 poświęcony kryzysowi finansowemu ${ }^{11}$.

\section{Wpływ kryzysu na gospodarstwa domowe w Polsce}

Podstawowe dane na temat polskich gospodarstw domowych w latach 20012013 przedstawiono w tabeli 1.

Pierwsze lata XXI w. były dla polskiej gospodarki okresem znacznych wahań koniunktury. Po wyjściu z recesji lat 2000-2002 Polska wkroczyła na ścieżkę szybkiego wzrostu. Maksimum dynamiki PKB zanotowano w 2007 roku, kiedy wskaźnik ten wzrósł o $6,8 \% \mathrm{w}$ stosunku do roku poprzedniego. W ciągu zaledwie 11 lat PKB w przeliczeniu na mieszkańca podwoiło się, osiągając w 2012 roku wartość blisko 22 tys. \$. Do Polski kryzys przybył z opóźnieniem. Znaczny spadek dynamiki zanotowano w 2009 roku - 1,6\%, a po odbiciu w latach 2010-2011, wskaźnik wzrostu znów spadł poniżej 2\%. Nie odnotowano jednak wyników ujemnych $\mathrm{w}$ przeciwieństwie do wielu państw Unii Europejskiej. W badanym okresie należy zauważyć znaczącą poprawę na rynku pracy. Poziom bezrobocia spadł z 20\% w 2002 do 7,1\% w 2008 roku. W następnych latach liczba bezrobotnych rosła, będąc efektem spowolnienia gospodarczego.

Spożycie w gospodarstwach domowych cały czas rosło. Maksimum osiągnęło w 2008 roku, kiedy zanotowano wzrost rzędu 6,1\%. W kolejnych latach dynamika nie była już tak duża i wahała się w granicach od 3,4 do 1\%. Nie zanotowano

${ }^{11}$ world-exchanges.org, financial times, mortgage exchange office. 


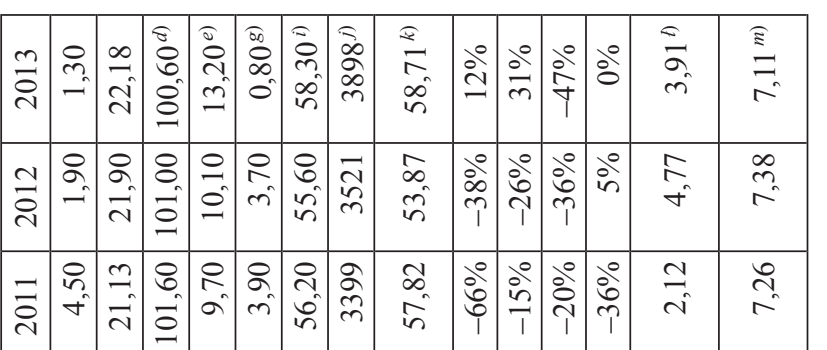

을

๙ิ่

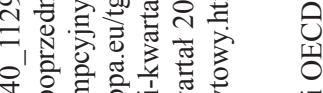

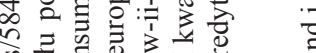

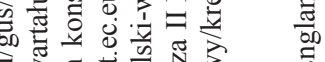

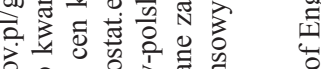

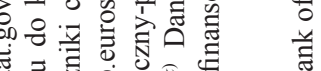

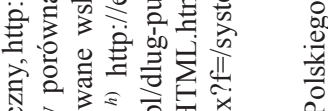

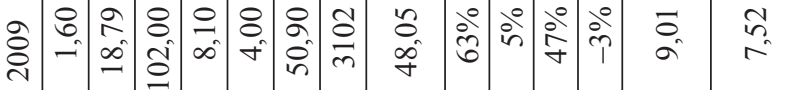

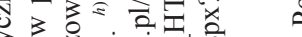

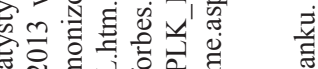

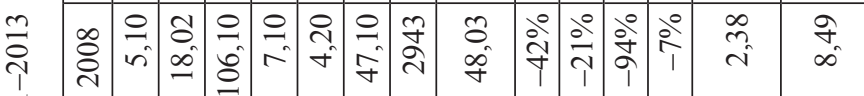
ते

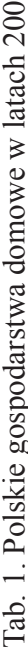

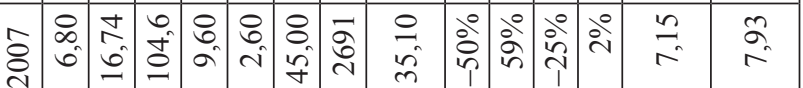

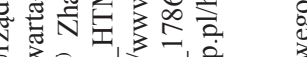

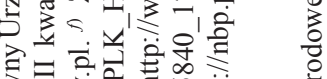

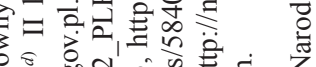

잉

.

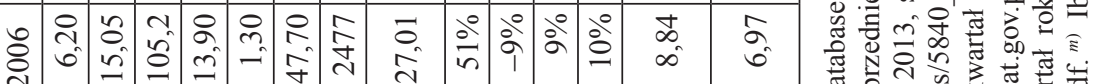

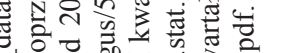

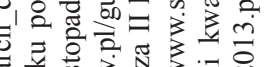

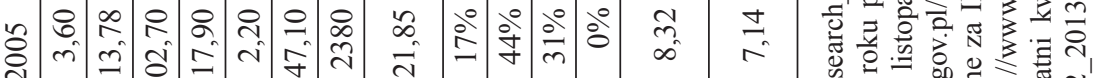

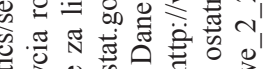

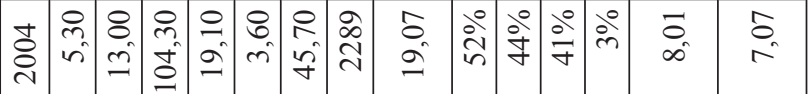

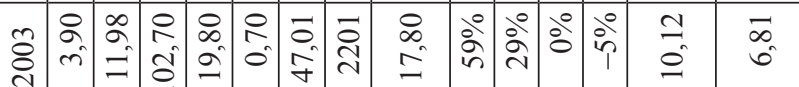

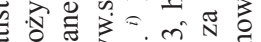

क्षे के

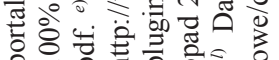

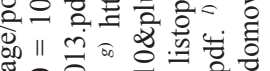

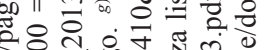

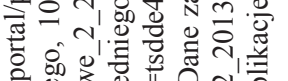

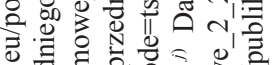

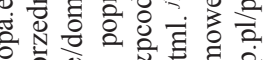

응

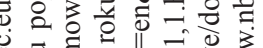

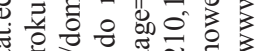

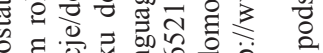

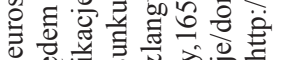

일

Q

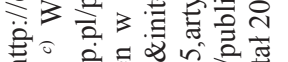

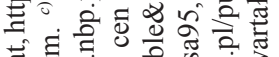

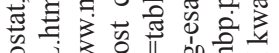

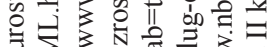

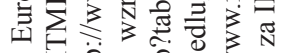

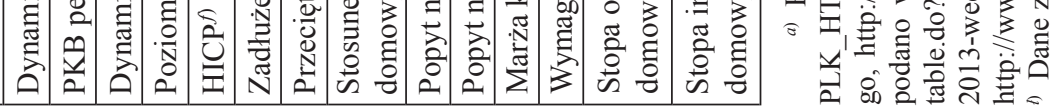

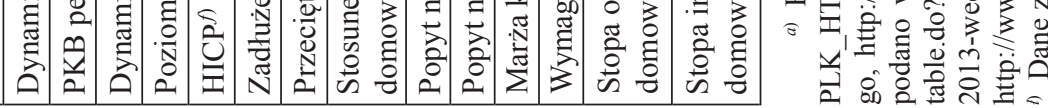

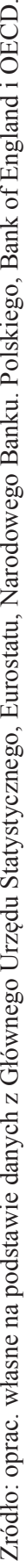


wyraźnych tendencji we wzroście cen mierzonych wskaźnikiem HICP. Zadłużenie Polski w stosunku do PKB w ciągu 11 lat wzrosło o przeszło 18\%. Szczególne nasilenie tego zjawiska nastąpiło w czasie kryzysu. Przeciętne wynagrodzenie brutto w każdym kolejnym roku wzrosło. Ponadto nie odnotowano znaczących spadków dynamiki po roku 2008. Długi gospodarstw domowych w stosunku do osiąganego dochodu uległy znacznemu zwiększeniu, z zaledwie $11,78 \%$ w 2001 roku do poziomu 53,87\% w 2012 (maksimum w 2011 roku - 57,82\%).

Według badań ankietowych przeprowadzonych przez Narodowy Bank Polski ${ }^{12}$, po 2007 roku, popyt na kredyt mieszkaniowy wśród gospodarstw domowych znacznie się zmniejszył. Podobna sytuacja wystąpiła na rynku kredytów konsumpcyjnych, w tym przypadku spadek zainteresowania był jednak mniejszy. Marża kredytowa w badanym okresie podlegała dość dużym wahaniom. Po wzrostach w latach 2004-2006 ankietowani zadeklarowali zdecydowany spadek tego wskaźnika. Wielkość zabezpieczeń kredytu mieszkaniowego dość regularnie spadała, ze znacznym nasileniem zjawiska w 2011 roku. Procentowa wartość oszczędności Polaków wyraźnie zmalała ze stanu 14,11\% w 2001 do zaledwie 4,77\% w 2012 roku. Wielkość inwestycji pozostała na względnie podobnym poziomie - w granicach od $6,22 \%$ do $8,49 \%$.

\section{Wpływ kryzysu na gospodarstwa domowe w Wielkiej Brytanii}

Podstawowe dane na temat brytyjskich gospodarstw domowych w latach 2001-2013 przedstawiono w tabeli 2.

W latach 2001-2007 brytyjska gospodarka rozwijała się stabilnie, w granicach 2,2-3,4\% rok do roku. Kryzys pojawił się w 2008 roku, kiedy PKB spadło o $0,8 \%$. Natomiast rok później gospodarka skurczyła się aż o 5,2\%. W następnych latach zanotowano nieznaczne ożywienie koniunktury, wzrost PKB nie przekraczał jednak $2 \%$. Dochód narodowy w przeliczeniu na jednego mieszkańca od 2006 roku wahał się w granicach 35 tys. \$. Dynamika spożycia rosła nieprzerwanie do 2008 roku, kiedy spadła o 0,2\% w stosunku do roku poprzedniego. W następnych latach przyrost jej wartości krążył wokół zera.

Kryzys finansowy spowodował znaczne pogorszenie na rynku pracy, szczególnie duży spadek zatrudnienia zanotowano na przełomie lat 2008-2009. W ogólnym rozrachunku bezrobocie na koniec 2012 roku, było o 3\% większe niż w 2001.

Wskaźnik HICP w latach 2001-2004 był stosunkowo stabilny. Większe wartości pojawily się w 2005 roku, kiedy sięgnął on powyżej 2\%. Kryzys znacznie nasilił przyrost cen, maksimum odnotowano w roku 2011, wynosiło on $+4,5 \%$. Inflacja w grudniu 2012 uplasowała się na poziomie 2,7\% według wskaźnika CPI

12 Ankieta przeprowadzana wśród komitetów kredytowych największych polskich banków - opinie na temat przewagi wzrostu lub spadku wskaźnika. 
(consumer price index). Jest to stan niezmienny w stosunku do listopada i października 2012 (w całym roku 2012 inflacja utrzymywała się na zbliżonym poziomie, np. maj $2012-2,8 \%$, sierpień - 2,5\%; dla porównania w grudniu 2011 roku poziom inflacji wyniósł $4,2 \%$ ). Według danych urzędu statystycznego, w grudniu 2012 roku odnotowano nieznaczną presję inflacyjną związaną z sezonem grzewczym i wyższymi rachunkami za energię. Wielkość inflacji w 2012 roku zrównoważyła niższe niż w grudniu 2011 roku ceny biletów lotniczych.

Zadłużenie Wielkiej Brytanii w stosunku do PKB ma silną tendencję wzrostową. W przeciągu 11 lat jego wartość procentowa zwiększyła się aż o 51,4\%. Tylko na przełomie 2008/2009 dług narodowy urósł o bagatela 15,2\%. Podobna sytuacja miała miejsce w przypadku gospodarstw domowych. Przeciętny Brytyjczyk w 2012 roku był zadłużony na 132,8\% swoich dochodów. Od 2008 roku wskaźnik ten jednak spada (maksimum w 2008 roku - 151,4\%).

Marża na kredyty ubezpieczone, zdaniem respondentów ankiety przeprowadzonej przez Bank of England, spadała w latach 2007-2009 i dość wyraźnie wzrosła w roku 2010. Przez następne dwa lata nie nastąpiły w tej materii znaczące zmiany. Pod względem wartości przyznawanych kredytów ubezpieczonych okres kryzysu dość znacznie je zmniejszył. Poprawa sytuacji nastąpiła w 2009 roku, a w kolejnych latach ustabilizowała się. O niechęci banków do udzielania kredytów może świadczyć również fakt, iż w latach 2007-2008 uległa zmniejszeniu kwota możliwa do pożyczenia w stosunku do osiąganych dochodów. Oszczędności brytyjskich gospodarstw znacznie stopniały w wyniku pogorszenia koniunktury, jednak począwszy od 2009, ich wielkość unormowała się na poziomie ok. 7\%. Kryzys odbił się również na prywatnych inwestycjach, po 2008 roku ich wskaźnik obniżył się o ok. $2 \%$ do poziomu $5,2-5,8 \%$.

\section{Podsumowanie i wnioski}

Obecnie gospodarka światowa ciągle znajduje się w kryzysie. Model rozwoju i model bankowości, który przez ostatnie lata dominował, nie działa tak, aby dalej zapewniał odpowiednio wysoki rozwój gospodarki światowej.

W rzeczywistości świat stoi przed trzema możliwościami. Jak twierdzi Paul Mason, pierwszą szansą jest utrzymanie obecnego modelu opartego na niskich płacach i wysokim długu w bardziej uregulowanych warunkach. Druga możliwość to całkowite porzucenie niekończącego się rozwoju ekonomicznego jako głównego celu. Trzecia zaś cechuje się oparciem wzrostu gospodarczego na zupełnie innych podstawach - powrót do wysokich płac, redystrybucji i uregulowanego systemu finansowego ${ }^{13}$.

${ }_{13}$ Paul Mason, Finansowy kataklizm, koniec wieku chciwości, Wydawnictwo Uniwersytetu Jagiellońskiego, Kraków 2010. 
Rozwiązanie trzecie, dotyczące szybko rozwijającej się gospodarki wykraczającej poza ramy keynesowkiej oraz neoliberalnej polityki, jest najlepsze. W tym rozwiązaniu teoria Minsky'ego przedstawia wytyczne, jak osiągnąć status gospodarki szybko rozwijającej się. Należą do nich przede wszystkim nacjonalizacja banków i firm ubezpieczeniowych, ściśle ograniczenia nałożone na spekulacje finansowe, zmiany struktury opodatkowania, aby służyło redystrybucji bogactwa w taki sposób, by także biedniejsza połowa populacji uczestniczyła w owocach rozwoju gospodarczego, tworząc wewnętrzny popyt, którego wzrost mógłby stać się odmiennym od kredytu kołem zamachowym gospodarki ${ }^{14}$.

Dla wielu osób takie rozwiązanie może wydawać się antykapitalistyczne, gdzie wolny rynek kojarzy się z kapitalizmem. Jednak te działania mają prowadzić do ratowania systemu kapitalistycznego, ochrony przed spekulacjami, niewłaściwą polityką finansową banków, a także nieodpowiedzialnym sprawowaniem rządów, które doprowadziły do deregulacji. Obecnie większość systemów bankowych w Europie, w tym w Wielkiej Brytanii, jest znacjonalizowana lub korzysta $\mathrm{z}$ dofinansowania państwa.

Kryzys finansowy negatywnie wpłynął przede wszystkim na gospodarkę realną państwa brytyjskiego. Ograniczył możliwości konsumpcyjne gospodarstw domowych oraz nastroje konsumentów, powodując spadek konsumpcji, która w Wielkiej Brytanii jest ważnym elementem PKB. Kryzys gospodarczy spowodował, że w tym kraju uruchomiono działania interwencyjne rządu oraz Banku Centralnego. Program naprawczy w Wielkiej Brytanii był wyceniany na setki miliardów dolarów. Konieczność sfinansowania tych działań pociągał za sobą wzrost długu publicznego, który w przeliczeniu na obywatela diametralnie wzrósł. To z kolei spowodowało, że obsługa nadmiernego długu publicznego przyczyni się do zwiększenia obciążeń budżetowych na wiele lat. Wynikiem tej sytuacji jest również wzrost podatków, które w konsekwencji zmniejszą dochód gospodarstw domowych oraz ich zdolności konsumpcyjne i inwestycyjne.

Gospodarka Polski była bardziej odporna na zawirowania kryzysowe. W państwie polskim podczas trwania kryzysu globalnego rząd podjął szereg przedsięwzięć mających na celu utrzymanie wzrostu gospodarczego. Do nich zalicza się ograniczanie niekorzystnych oddziaływań kryzysu. W listopadzie 2008 roku rząd Polski przygotował i wprowadził serię działań zapobiegających kryzysowi finansowemu. Plan Stabilności i Rozwoju posiadał szereg instrumentów, których zadaniem było powiększenie zaufania na rynkach międzybankowych oraz zapobieganie spadku akcji kredytowej. Ponadto Narodowy Bank Polski podjął dodatkowe działanie w obrębie systemu finansowego. Za sprawą przyjętego Pakietu Zaufania udało się ograniczyć ryzyko kredytowe i ryzyko związane z płynnością banków. Niemniej jednak polski rząd podjął również przedsięwzięcia w kierunku:

${ }^{14}$ Ibidem. 
- wzrostu popytu konsumpcyjnego - ograniczając podatek i obciążenia parapodatkowe;

- popytu inwestycyjnego - ograniczając bariery administracyjne;

- umożliwiając łatwy dostęp do środków unijnych,

- rozwijając podjęte inicjatyw,

- wprowadzając udogodnienia dotyczące wykorzystaniu pozyskanych środków unijnych,

- stosując możliwe udogodnienia w sferze relacji partnerskich sektorów publicznych i prywatnych ${ }^{15}$.

Kryzys finansowy odcisnął swoje piętno na budżecie gospodarstw domowych, na ich możliwościach konsumpcyjnych oraz inwestycyjnych. Również strach przed pogarszaniem się perspektyw gospodarczych, w tym przede wszystkim perspektyw dotyczących zarobków gospodarstw domowych, sprawił, iż zaczęły one ograniczać wydatki, które bezpośrednio wpłynęły na spadek sprzedaży przedsiębiorstw, ceny ich dóbr i usług, a w konsekwencji zmniejszyły wartości ich przychodów ze sprzedaży.

\section{Bibliografia}

Adamiec J., P. Russel, Kryzys finansowy. Wybrane zagadnienia. Wydawnictwo Sejmowe, Warszawa 2009.

Biuro Analiz Sejmowych, Kryzys finansowy wybrane zagadnienia, Wydawnictwo Sejmowe, Warszawa 2009.

Gaudemet P. M., Molinier J., Finanse publiczne, PWE Warszawa 2000.

Kindleberger Ch., Szaleństwo, panika, krach, WIG Press, Warszawa 1999.

Kosek-Wojnar M., Surówka K., Podstawy finansów samorządu terytorialnego, PWN, Warszawa 2007.

Kusiak F., Kryzys na rynku nieruchomości ze szczególnym uwzględnieniem sprzedaży niezabudowanych działek gruntu we Wroctawiu w latach 2008-2009, „Kultura - Historia - Globalizacja” 2011, nr 9.

Mazurek S., Mechanizm międzynarodowej transmisji kryzysów gospodarczych, Akademia Ekonomiczna we Wrocławiu, Wrocław 2007.

Ministerstwo Gospodarki, Koniunktura gospodarcza w wybranych krajach w okresie kryzysu finansowego, Warszawa 2011.

Minsky H.P., Stabilising an Unstable Economy, New York 2008.

Morawski W., Kronika kryzysów gospodarczych, TRIO, Warszawa 2003.

Mynsky H.P., John Maynard Keynes, New York 2008.

Nawrot W., Globalny kryzys finansowy XXI wieku. Przyczyny, przebieg, skutki, prognozy, CeDeWu, Warszawa 2009.

Owsiak S., Finanse publiczne, PWE, 2015.

Raus D., Materiaty i studia. Determinanty i metody szacowania ryzyka kryzysu walutowego, NBP, Warszawa 2000.

15 www.epp.eurostat.ec.europa.eu [dostęp 2.02.2014]. 
Słowiński A., Przyczyny i następstwa kryzysu walutowego, PWN, Warszawa 2001.

Ustawa z dnia 1 lipca 2009 r. o łagodzeniu skutków kryzysu ekonomicznego dla pracowników i przedsiębiorców, Dz. U. 2009 Nr 125, poz. 1035.

Ustawa z dnia 11 maja 2012 r. o zmianie ustawy o emeryturach i rentach z Funduszu Ubezpieczeń Społecznych oraz niektórych innych ustaw, Dz. U. z 2009 r. Nr 153, poz. 1227, z późn. zm., art. 129 ust. 3.

Ustawa z dnia 11 marca 2004 r. o podatku od towarów i usług, Dz. U. 2004 Nr 54, poz. 535.

Zyżyński J., Budżet i polityka podatkowa, PWN, Warszawa, 2010.

Żabińska J. (red.), Kryzysy finansowe, ich przyczyny, skutki i sposoby przezwyciężania, Akademia Ekonomiczna im. Karola Adamieckiego, Katowice 2000.

\section{Zasoby internetowe}

www.epp.eurostat.ec.europa.eu

www.orka.sejm.gov.pl, Kryzys finansowy wybrane zagadnienia

www.stat.gov.pl.

\section{Streszczenie}

$\mathrm{Na}$ gospodarstwach domowych odcisnęły swoje piętno problemy, które pojawiły się na rynkach finansowych i rynkach akcji. Konsekwencją kryzysu finansowego dla gospodarstw domowych były ograniczenia w udzielaniu kredytów przez banki oraz nagły wzrost cen nowych kredytów. Recesja, która powstała na rynkach akcji, zmniejszyła możliwości osiągnięcia dochodów inwestycyjnych. Szybkie załamanie rynku obligacji i akcji spowodowało ogromne straty dla osób inwestujących. Gospodarstwa domowe stanowią jedną z grup aktywnych inwestorów indywidualnych, ale z drugiej strony są uczestnikami funduszy inwestycyjnych. Oszczędności gospodarstw domowych były zdeponowane na giełdzie, więc w recesji straciły pieniądze - bezpośrednio lub za pośrednictwem funduszy inwestycyjnych.

Słowa kluczowe: bank, Wielka Brytania, Polska gospodarstw domowych, finansowanie, kryzys

Numer klasyfikacji JEL: L26, L53 